\title{
El diario La Nación versus el sindicalismo argentino. La construcción de un enemigo "subversivo" de la democracia (1983-1987)
}

\author{
César Luis Díaz \\ Centro de Estudios en Historia/Comunicación/Periodismo/Medios, Facultad \\ de Periodismo y Comunicación Social, Universidad Nacional de La Plata. \\ tatodiaz60@gmail.com \\ ORCID: http://orcid.org/0000-0003-0816-642X
}

\author{
Mario Jorge Giménez \\ Centro de Estudios en Historia/Comunicación/Periodismo/Medios, Facultad \\ de Periodismo y Comunicación Social, Universidad Nacional de La Plata. \\ mariojgimenez@yahoo.com.ar \\ ORCID http://orcid.org/0000-0003-2464-4671
}

Fecha de finalización: 2 de octubre de 2020

Recibido: 2 de octubre de 2020

Aceptado: 4 de junio de 2021

DOI: https://doi.org/10.26422/aucom.2021.1001.dia

\section{Resumen}

En este artículo se examina la posición editorial del diario La Nación sobre el comportamiento del sindicalismo durante el Gobierno de Raúl Alfonsín, entre los años 1983 y 1987. Considerando al diario como actor político, se examinarán sus estrategias discursivas, se identificará al o a los destinatarios a los cuales dirigía su mensaje y la utilización de los recursos retóricos de los cuales se valía para enunciar el accionar sindical. El diario, exponente del pensamiento liberal, cuestionó las políticas estatistas del peronismo, como también la sindicalización masiva de trabajadores ocurrida a partir de 1945. Uno de los motivos por los cuales contribuyó con el golpe cívico-militar de 1976 estuvo relacionado con la restauración del “orden”. Dado que consideraba al movimiento obrero responsable de su pérdida, avaló las medidas punitorias ejecutadas por la dictadura que, inspiradas en la doctrina de la seguridad nacional, tuvieron como resultado la intervención a los gremios, la desaparición, el presidio y el exilio de numerosos dirigentes sindicales. Después de la derrota en la guerra de Malvinas, destinaría una importante cantidad de editoriales para oponerse a las medidas de fuerza ejecutadas por las entidades representativas de los trabajadores, acusándolas de atentar contra la democratización y la convivencia social. Una vez asumidas las autoridades elegidas por el pueblo, seguiría fustigando el comportamiento de gremialistas, descalificando su metodología de lucha por considerarla contraria a la estabilidad 
de la democracia y el régimen representativo y republicano. Por esa razón, no dudó en reputar como subversiva la actitud del sindicalismo argentino.

Palabras clave: diario, La Nación, sindicalismo, alfonsinismo, subversión.

\section{La Nación newspaper against the Argentine unions: constructing a "subversive" enemy of democracy (1983-1987)} Abstract

This article examines the editorial stance adopted by La Nación newspaper in regard to Argentine labor unions during Raúl Alfonsín's presidency (1983-1987). We consider this newspaper to be a political actor and address its discursive strategies. We also identify its audience or readership and its use of rhetorical devices to report on union-related news. This newspaper, an exponent of conservative thought, questioned the statist policies of Peronism as well as the widespread unionization of workers from 1945 onward. Indeed, one of the reasons why this newspaper contributed to the civic-military coup of 1976 was its desire to restore "order." It linked the labor movement to the destruction of this order and therefore supported the punitive measures enacted by the ensuing dictatorship. These measures, which followed the doctrine of national security, led to the military intervention of unions and to the disappearance, incarceration, and exile of numerous union leaders. After Argentina's defeat during the Falkland War, La Nación would publish many editorials opposed to the protests organized by workers' groups, accusing them of weakening democracy and social harmony. Even after the democratic process was restored, the newspaper kept condemning the behavior of unions and disparaging their fight, claiming it was antithetical to the stability of democracy and of a representative and republican form of government. For this reason, it labeled the attitude of Argentine unions as "subversive."

Keywords: La Nación, unions, Raúl Alfonsín, subversión.

\section{O diário La Nación versus o sindicalismo argentino. A construção de um inimigo "subversivo" da democracia (1983-1987)}

\section{Resumo}

Este artigo examina a posição editorial do jornal La Nación sobre o comportamento do sindicalismo durante o governo de Raúl Alfonsín, entre 1983 e 1987. Considerando o jornal como um ator político, serão examinadas suas estratégias discursivas, identificando a (s) pessoa (s) destinatária (s) a quem dirigiu sua mensagem e o uso dos recursos retóricos com que se valeu para enunciar a ação sindical.

O jornal, expoente do pensamento liberal, questionou as políticas estatistas do peronismo, bem como a massiva sindicalização dos trabalhadores ocorrida desde 1945. Uma das razões pelas quais contribuiu para o golpe cívico militar de 1976 está relacionada à restauração da "ordem". Ao considerar o movimento operário responsável por sua perda, endossou as medidas punitivas da ditadura que, inspiradas na doutrina da segurança nacional, resultaram na intervenção sindical, desaparecimento, prisão e exílio de numerosos dirigentes sindicais. Depois da derrota nas Malvinas, o jornal destinaria um número significativo de editoriais para se opor às medidas de força levadas a cabo pelas organizações representativas dos trabalhadores, acusando-as de atentar contra a democratização e a convivência social. Tendo assumido as autoridades eleitas pelo povo, continuaria a agredir o comportamento dos sindicalistas, desqualificando sua metodologia de luta como contrária à estabilidade da democracia e do regime representativo e republicano. Devido a isso, não hesitou em considerar subversiva a atitude do sindicalismo argentino.

Palavras chave: jornal, La Nación, sindicalismo, alfonsinismo, subversão. 


\section{Austral Comunicación \\ Volumen 10, número 1 (junio de 2021): 321-347 ISSN (I) 2313-9129. ISSN (E) 2313-9137}

\section{Presentación}

Este artículo se propone examinar la construcción editorial que efectuó el diario La Nación ${ }^{1}$ sobre el sindicalismo y la valoración de su comportamiento como contrario al sistema democrático durante los primeros cuatro años del Gobierno de Raúl Alfonsín. ${ }^{2}$ El recorte temporal obedece a que el presente es resultado del avance de investigación de un proyecto en el cual se indagan los editoriales de La Nación durante el Gobierno de Raúl Alfonsín (1983-1989). En el periodo 1983-1987 editorializó en 151 oportunidades sobre el movimiento obrero y en el $75 \%$ de las notas criticó su accionar.

Aquí solo se centrará la atención en el posicionamiento adoptado en los 28 editoriales en los cuales La Nación abordó acontecimientos relacionados con acciones de violencia contra el sistema institucional, 21 de los cuales corresponden al accionar sindical y al comportamiento de los trabajadores, que eran valorados por el matutino como "subversivos" o bien como intentos para anular alguno de los tres poderes de la República. El recorte temático obedece a que si bien otros artículos han abordado el tratamiento editorial de La Nación sobre el comportamiento del sindicalismo durante los primeros dos años del Gobierno de Alfonsín, dan cuenta de su cuestionamiento a la metodología de lucha que desarrollaba presentándolo como "antisocial e incivilizado" y solo llega a insinuar que eventualmente apreció su comportamiento como "subversivo" (Díaz y Giménez, 2018b).

Esta posición por parte del diario registra como antecedente el haber contribuido en la construcción del golpe cívico-militar de 1976 (Díaz et al., 2002), responsabilizando al sindicalismo como uno de los principales protagonistas de la crisis del tercer Gobierno peronista. Asimismo, una vez entronizada la Junta Militar, avaló la instauración del terrorismo de Estado (Díaz, 2011) y justificó las medidas represivas que la

\footnotetext{
El diario fue fundado por Bartolomé Mitre el 4 de enero de 1870, anunciando en su primer número que sería una "tribuna de doctrina" del liberalismo vernáculo. Desde ese momento, supo interpretar los intereses de los sectores tradicionales vinculados a las familias que conformaban la burguesía agroexportadora y, por ende, se encontraban en las posiciones más altas de la estructura del poder político, del sistema económico y de la jerarquía del reconocimiento social. Compartían el hábito de la lectura de sus páginas, característica que continuó vigente en la etapa indagada y aún en la actualidad. Recordemos que este pacto de lectura que se establece entre el medio y su lector ante el acto de comprar un diario importa "un acto ritual, porque es adquirir una matriz de decodificación de los hechos sociales que organiza la realidad que al mismo tiempo construye. Mediante ellas al lector se le ofrecen formas de ver el mundo social. La fidelidad para con un diario puede llegar a ser mayor que para otros objetos igualmente familiares" (Sidicaro, 1993, p. 7).

2 En la serie de entrevistas que Hugo Caligaris y Encarnación Ezcurra (2021) le realizaron a Claudio Escribano, quien entre 1981 y 1995 ocupó la Secretaría General de Redacción del matutino aquí examinado, le manifestaron su percepción de que él "encarnaba a La Nación”. Esta definición sería aceptada por el entrevistado solo a condición de que "si esto es así, es una Nación idealizada, que no tiene necesariamente por qué ser La Nación real". A partir de lo cual, ambos acotaron: “¿Cómo era esa Nación idealizada por Escribano? Para sus lectores, fue durante mucho tiempo la última barricada de una clase social que se sentía amenazada más por las insolencias del populismo peronista que por el avance del comunismo. Era la defensora del orden establecido y la difusora de la gran cultura europea, pero también la discreción, el tono contenido, la elegancia tanto para la alabanza como para la crítica, una preferencia por la regularidad de las instituciones y un liberalismo en materia de costumbres y gustos en la medida en que afectaran únicamente a los individuos" (Caligaris y Ezcurra, 2021, p. 12).
} 
César Luis Díaz, Mario Jorge Giménez

El diario La Nación versus el sindicalismo argentino. La construcción de un enemigo "subversivo" de la democracia (1983-1987)

dictadura destinó al sindicalismo hasta el conflicto militar en el Atlántico Sur (Díaz y Giménez, 2016).

Producida la derrota en la guerra de Malvinas (1982), el matutino, a pesar de su reconocimiento sobre la magnitud de la crisis económica en la Argentina, rechazó las medidas de fuerza llevadas a cabo por las organizaciones gremiales. Al mismo tiempo, descalificaba a sus representantes, pues consideraba que actuaban en pos de beneficios personales y del Partido Justicialista (PJ), explicando además que perturbaban el proceso de democratización y la convivencia social de los argentinos (Díaz y Giménez, 2017a).

Por entonces, Raúl Alfonsín, candidato presidencial por la Unión Cívica Radical (UCR), denunció la existencia de un pacto sindical-militar ${ }^{3}$ por medio del cual un posible triunfo del PJ en las elecciones del 30 de octubre de 1983 les aseguraría a los uniformados total impunidad frente a los delitos de lesa humanidad cometidos desde 1976. La Nación eludió jerarquizar editorialmente tamaña imputación, al tiempo que se anticipó a la acusación del candidato radical atribuyendo, a principios de abril de 1983, la conformación de una suerte de entente "sindical-militar", convencido de que las numerosas medidas de fuerza gremiales se sucedían por la complacencia de los gobernantes (Díaz y Giménez, 2017a).

El matutino no ocultó su preferencia por el candidato radical (Díaz y Giménez, 2017b), quien, de manera recíproca, "se relacionaba con los creadores de la agenda pública en dosis moderadas: se despertaba con La Nación [...] acostumbrado a que el diario de los Mitre organizara su modo de ver la actualidad nacional" (Sivak, 2015, p. 70). De todos modos, la columna editorial ignoró la propuesta de "democratización sindical" y el propósito de lograr que sus líderes subordinaran la defensa de los intereses sectoriales en beneficio de la economía del país (Alfonsín, 1984, p. 44). ${ }^{4} \mathrm{El}$ diario consideraba que la derrota del PJ en las elecciones de octubre de 1983 podía constituirse en un punto de inflexión, inaugurando una nueva tradición político-institucional

\footnotetext{
3 Gaudio y Thompson (1990) consideran que la denuncia, producida el 25 de abril de 1983, "poseía una profunda significación programática, no solo porque exhibía una clara consistencia con la concepción sindical del radicalismo sino porque también integraba el eje fundamental del proceso de democratización que -según aquel- requería el país" (p. 16).

4 Un indicio de las prevenciones que el matutino examinado podía albergar sobre el por entonces candidato de la UCR puede rastrearse en la visión del responsable de la línea editorial, quien coincidió con la definición que publicara la revista Esquiú en la segunda mitad de la década de 1980 al definir al radical balbinista Claudio Escribano como "alguien que soñaba con que el liberalismo pasara por la Unión Cívica Radical” (Caligaris y Ezcurra, 2021, p. 252). Al ser consultado por sus biógrafos sobre Alfonsín, remarcaba "que le quedaban sedimentos de posiciones anacrónicas. Que en su pensamiento se reflejaba otro tiempo, una visión de la economía negativa para la Argentina, y que no había conseguido sacarse del todo de encima ese compromiso de la intransigencia radical con las posiciones programáticas de la segunda parte de los años 40. Uno no sabía si eran más regulatorias las proposiciones radicales de la economía o las del propio Perón" (Caligaris y Ezcurra, 2021, p. 262).
} 
que terminara con las prácticas y el poder político del peronismo (Díaz y Giménez, 2018a), como también el de su columna vertebral: ${ }^{5}$ el movimiento obrero organizado.

\section{Aspectos teórico-metodológicos}

Este artículo estudia el posicionamiento editorial del diario La Nación sobre el sindicalismo basado en el método cualitativo, que "depende fundamentalmente de la observación de los actores en su propio terreno y de la interacción con ellos en su lenguaje y con sus mismos términos [...] a fin de captar el sentido de la acción de los participantes" (Vasilachis, 1992, p. 32). Por ello, se apoya en una perspectiva de análisis centrada en la historia del periodismo, que contempla ciertos componentes históricos, comunicacionales y lingüísticos utilizados en la retórica del medio examinado. La diversidad del repertorio teórico considerado obedece a la intención de indagar el corpus mediante una mirada concurrente construida a partir de distintos enfoques y no bajo el prisma de un paradigma en particular. El diario es considerado como un "actor político" (Borrat, 1989) que interactúa con los demás actores de un sistema institucional, en este caso, los sindicatos, los partidos políticos y los distintos poderes del Estado. Con el propósito de interpelarlos, el diario construyó "estrategias enunciativas" (Verón, 2005, p. 197) formuladas mediante la producción de un "discurso político"6 que postula la construcción de un "destinatario genérico [denominado] ciudadano nacional" (asociado al colectivo nación')" (Verón, 2005, p. 195) y, en otro nivel, para tres subespecies de destinatarios: el prodestinatario, al que se apunta a través de mecanismos de fortalecimiento de la creencia compartida, el paradestinatario, blanco de mecanismos del orden de la persuasión, y el antidestinatario, blanco de las figuras de lo polémico (Verón, 2005, p. 196).

La Nación, al igual que los demás órganos del sistema mediático, ejercen su poder de legitimación mediante una retórica que, como "toda unidad léxica es, en un cierto sentido, subjetiva, pues las 'palabras' empleadas son símbolos sustitutivos e interpretativos de las 'cosas"' (Kerbrat-Orecchioni, 1997, pp. 91-92). Esta autora clasifica a estos "subjetivemas" en afectivos y evaluativos, dividiendo a los últimos en axiológicos y no axiológicos. Los afectivos son los que enuncian al mismo tiempo una propiedad del objeto y una reacción emocional del sujeto frente a ese objeto, mientras que los evaluativos se dividen en dos tipos según el nivel de valoración que efectúan: los no axiológicos, que no realizan necesariamente juicio de valor o compromiso afectivo por parte del locutor, pero sí implican una evaluación cualitativa o cuantitativa del objeto, y

\footnotetext{
Por entonces, el cargo de vicepresidente del PJ lo ejercía Lorenzo Miguel, quien era además secretario general de la Unión Obrera Metalúrgica (UOM) y de 62 Organizaciones Sindicales Peronistas. En las elecciones de 1983 "fueron electos doce diputados peronistas de origen sindical y uno radical” (Ferraresi y Galasso, 2018, p. 246).

6 Además de la categoría "discurso político", Verón (2005, p. 196) identifica en la prensa los tipos de "discurso de la información" y "discurso publicitario".

Énfasis en el original.
} 
César Luis Díaz, Mario Jorge Giménez

El diario La Nación versus el sindicalismo argentino. La construcción de un enemigo "subversivo" de la democracia (1983-1987)

los axiológicos, que aplican al objeto un juicio de valor positivo o negativo y se los considera doblemente subjetivos. Por un lado, su uso varía según la naturaleza del sujeto de la enunciación (reflejan su competencia ideológica); por otro, manifiestan una toma de posición a favor o en contra del objeto (Kerbrat-Orecchioni, 1997, pp. 111-123).

Como parte constitutiva de la retórica periodística se atenderá también a las figuras utilizadas, por ejemplo

\begin{abstract}
el principio de autoridad intercalado en la exposición de un argumento, permite deducir una conclusión de ese argumento mismo sin necesidad de demostrar su verdad [...] y la concesión siguiendo una estrategia esencial al liberalismo concede la palabra a un adversario real o ficticio aunque argumente en dirección opuesta para reforzar la imagen de objetividad de nuestra propia conclusión. (Ducrot, 1989, p. 149)
\end{abstract}

Los "pares antagónicos", es decir, "los antónimos que van por parejas complementarias [...] constituyendo pares originales que un análisis contrastativo debe destacar" (Maingueneau, 1989, p. 66). También nos valdremos de ciertos conceptos como la "retórica civilizatoria" (Steimberg, 2000) y sobre las conceptualizaciones aplicadas en los sistemas políticos en la sociedad de masas (Bobbio, 2010; Laclau, 2010).

Las categorías propuestas por Miquel Rodrigo Alsina (1991) para clasificar los tipos de valoraciones sobre el terrorismo ofician de apoyatura teórica en la identificación de las variantes discursivas a las que apeló La Nación, dada la asociación que efectuaba del comportamiento del actor sindical con el de las organizaciones armadas que actuaron en la década del 70. Este autor reconoce cuatro tipos de discursos periodísticos sobre el terrorismo: el discurso jurídico, que hace referencia al carácter criminal del terrorismo e intenta despolitizarlo, presentándolo con un tratamiento jurídico especial: es el discurso de la ilegalidad; el discurso patológico, que se define como aquel en el cual el terrorismo pasa a ser un problema psiquiátrico, clínico, valorándolo como un acto de enajenación; el discurso político, reconociéndolo como una forma de violencia que se realiza para alcanzar fines sociales superiores más allá del mero acto de violencia; y el discurso militar, aquel que plantea al terrorismo como un acto de guerra, que legitima, aun sin buscarlo, a los dos contendientes, aunque la pretensión última del terrorismo sea suplantar al Estado (Rodrigo Alsina, 1991, p. 81).

\title{
La Nación y el comportamiento “antidemocrático" del sindicalismo en los primeros años de Alfonsín (1983-1985)
}

Después de más de cincuenta años de interrupciones golpistas a los Gobiernos surgidos de las urnas, la administración radical entendía que para consolidar la democracia el sindicalismo debía someterse también a un proceso de "democratización". Sin embargo, para los sindicalistas, la prioridad era recuperar los derechos laborales conculcados y la autonomía de los sindicatos, pues durante la dictadura habían sufrido 


\section{Austral Comunicación \\ Volumen 10, número 1 (junio de 2021): 321-347 ISSN (I) 2313-9129. ISSN (E) 2313-9137}

la disolución de la Confederación General del Trabajo (CGT), la intervención de los sindicatos, la desaparición y la detención de miles de dirigentes y la modificación de toda la legislación que beneficiaba a los trabajadores, tanto el derecho a discutir sus condiciones de trabajo a través de comisiones paritarias como la que les proporcionaba el manejo de sus obras sociales.

La diferencia de prioridades en estos dos actores fundamentales del sistema democrático, tal como se entiende en las democracias modernas (Bobbio, 2010, p. 30), impidió que se produjera una interacción constructiva entre ambos. El Gobierno deslegitimaba a la dirigencia sindical por su adscripción mayoritaria al PJ, omitiendo que esa posición tenía un importante grado de correlatividad con la identificación partidaria de la mayor parte de la clase trabajadora. En este punto es razonable aclarar que el matutino continuó abrevando en aquella visión doctrinaria que desde fines del siglo XIX y principios del XX miró con desconfianza al pluralismo siempre emergente. Es decir, interpretó que el crecimiento "de una sociedad en la que aumentó el número de ciudadanos activos mediante el sufragio universal, con la formación de sindicatos cada vez más fuertes y de partidos de masas que aumentaron las razones de conflicto y su extensión" (Bobbio, 2010, p. 148), perjudicaría la estabilidad institucional liberal que preconizaba.

Alfonsín, entre sus primeras medidas, presentó en el Congreso de la Nación un proyecto de ley que facilitaría la modificación de las conducciones en las organizaciones gremiales. ${ }^{8}$ Los sindicalistas no solo se opusieron en declaraciones y actos callejeros a la aprobación de la norma, sino que además reafirmaron la estrategia de confrontación que venían sosteniendo desde los últimos años de la dictadura cívico-militar en pos de recuperar los derechos laborales.

El diario, sin defender la propuesta gubernamental, ante la advertencia de la Unión Obrera Metalúrgica (UOM) de tomar las fábricas para asegurar el cumplimiento de sus reclamos, calificó esa acción con un discurso jurídico titulado "Un delito con anuncio previo" (1983). En la nota, se dirigía al Gobierno como paradestinatario y proponía la figura del par antagónico para explicar que la conducta del sindicalismo contrastaba con la de "la ciudadanía que optó por la democracia" (Un delito con anuncio previo, 1983). Además, en representación del ciudadano nacional, advertía que "el país

\footnotetext{
8 Gaudio y Thompson (1990) explican que el proyecto de Ley de Reordenamiento Sindical presentado por el Poder Ejecutivo al Congreso de la Nación "consistía, en esencia, en la convocatoria a comicios gremiales bajo un régimen electoral especialmente diseñado a tal efecto. Se apuntaba a democratizar los mecanismos de acceso al control de dichas organizaciones y para ello procuraba valerse de una eventual intervención del poder estatal ejercido en el interior mismo de las entidades laborales. En él se contemplaba asimismo que las minorías estarían representadas en un 33\% en la conformación de las conducciones y que 'por esta vez’ no tendrían aplicación las cláusulas sobre antigüedad y los avales requeridos para ser candidato. Hasta tanto se consumara el acto eleccionario -que sería controlado por la justicia electoral- los sindicatos serían en su totalidad administrados por representantes del ministerio de trabajo designado a tal efecto" (p. 36).
} 
César Luis Díaz, Mario Jorge Giménez

El diario La Nación versus el sindicalismo argentino. La construcción de un enemigo "subversivo" de la democracia (1983-1987)

se empeña actualmente en curar las profundas heridas dejadas por una etapa aciaga vivida al margen de estos principios" (Un delito con anuncio previo, 1983). Con el fin de reafirmar su compromiso con la institucionalidad recuperada, a dos semanas de que Alfonsín asumiera la presidencia, adoptó una postura combativa y, mediante un discurso de tipo militar, sentenció: "La democracia no debe entenderse como una actitud de indefensión ante quienes pretenden destruirla. Vivir en democracia significa, también, defenderla de sus enemigos" (Un delito con anuncio previo, 1983).

Después de emparentar el accionar sindical con delitos contemplados en el Código Penal, la huelga y los piquetes que protagonizaron los trabajadores del transporte público en la ciudad de Córdoba ${ }^{9}$ lo llevaron a titular un editorial mediante un mensaje patológico "La violencia como argumento" (1984). En el desarrollo del artículo, después de describir el incendio y el ataque a balazos contra transportes de pasajeros producidos por los huelguistas, aplicó el recurso de la analogía con el fin de equiparar ese comportamiento con el de las "bandas subversivas" (La violencia como argumento, 1984) que actuaron durante la década del 70. Además, transmitía a un paradestinatario lector:
Mucho costó volver a gozar de niveles aceptables de seguridad y de tranquilidad, aunque no faltan, inclusive, las voces que sostienen -en muchos casos sin duda con razón- que se pagó por ello un precio excesivo, pues comprometió a los hombres de armas con meto- dologías que nadie quiere ver repetidas y ha dejado secuelas que siguen siendo motivo de debate cotidiano. (La violencia como argumento, 1984)

Tesitura que, a su vez, también legitimó la política de juzgamiento a los represores llevada a cabo por el presidente Alfonsín (Crenzel, 2015). Resulta elocuente que el matutino tomara distancia de la siniestra metodología dictatorial al incluirse en el colectivo "nadie" para rechazar su reiteración, al tiempo que aludía tácitamente a la posibilidad de un nuevo golpe de Estado y, por ello, a la necesidad de sofocar el proclamado resurgimiento subversivo.

Cuando la Secretaría de Educación de la Municipalidad de la ciudad de Buenos Aires reincorporó a docentes que habían sido expulsados durante la dictadura cívico-militar, La Nación, mediante un discurso político, le recordó al paradestinatario lector que la separación de esos trabajadores de la educación había obedecido a que, antes de 1976, "se registraron en los ambientes educativos de nuestro país actitudes y hechos que constituyeron una amenaza efectiva para la subsistencia de las instituciones democráticas y de las expresiones fundamentales de la tradición cultural argentina" (Docentes reincorporados, 1984). Mensaje que, mediante el recurso de la concesión, si bien no cuestionaba la reincorporación de los docentes, remarcaba:

El matutino volvería sobre los conflictos ocurridos en Córdoba, destacando siempre el nivel de violencia, en las columnas "Innecesaria amenaza a la paz social" (1985) y "Violencia callejera en Córdoba" (1985) 


\title{
Austral Comunicación \\ Volumen 10, número 1 (junio de 2021): 321-347 ISSN (I) 2313-9129. ISSN (E) 2313-9137
}

\begin{abstract}
No es posible borrar de la memoria los signos de infiltración ideológica que se advirtieron en los distintos niveles de la enseñanza en los años que siguieron a 1970 y los agresivos intentos de catequización que ciertas tendencias totalitarias -cuyas coincidencias con los sectores de la subversión no era difícil descubrir- pretendieron llevar adelante no sólo en las aulas universitarias sino también en las de los niveles restantes del sistema educativo. (Docentes reincorporados, 1984)
\end{abstract}

Así, mientras las autoridades democráticas dejaban sin vigencia una sanción aplicada por quienes ejercieron el Gobierno de facto, insistía en atribuir fines subversivos al trabajo de los docentes reintegrados a sus cátedras.

Por el contrario, la colocación de explosivos en sedes partidarias y medios de comunicación, como también las amenazas a periodistas que comenzaron a efectuarse antes, durante y después de sustanciarse los juicios a las Juntas Militares (del 22 de abril al 9 de diciembre de 1985), si bien fueron rechazados en distintos editoriales, nunca calificó de subversivos a sus autores ${ }^{10} \mathrm{ni}$ sostuvo que sus objetivos fueran golpistas.

\section{Algunas manifestaciones callejeras desde la perspectiva de La Nación a partir de 1986}

Durante el segundo bienio del Gobierno democrático, la dirigencia gremial sostuvo sin solución de continuidad el comportamiento desarrollado desde fines de la dictadura cívico-militar, produciendo siete paros generales y un sinnúmero de medidas de fuerza sectoriales que fueron severamente cuestionadas por La Nación. Para conmover a su paradestinatario lector, poco antes de finalizar 1986, publicitó una estadística que arrojaba, a su entender, cifras alarmantes, pues en un año se ejecutaron " 595 medidas de fuerza, lo que da un promedio de 49,58 movimientos mensuales, a razón de 1,63 diarios" (Cifras que alarman, 1986). Buena parte de ellas se concentraría en la primera mitad del año, siendo acompañadas por piquetes de un alto nivel de violencia. Esto produjo una reacción editorial dirigida a denostar a los sindicalistas, no solo como perturbadores antisociales o por actuar con fines políticos partidarios o corporativos, sino también como continuadores de aquellos actos "subversivos" sucedidos entre 1983 y 1985.

Sin embargo, la primera advertencia sobre un rebrote subversivo durante el segundo bienio democrático no fue una medida de fuerza encabezada por el sindicalismo, pues el título del editorial - "Otra vez la violencia en las calles" (1986)- aludía a la

\footnotetext{
${ }^{10}$ Las columnas se titularon: “Bombas en la madrugada” (1985), “Metodología de las bombas” (1985), “El Estado y la seguridad" (1985), "Atentados criminales" (1985), “Condena unánime de la violencia” (1985), "Atentado en la iglesia de San Ignacio" (1985).
} 
César Luis Díaz, Mario Jorge Giménez

El diario La Nación versus el sindicalismo argentino. La construcción de un enemigo "subversivo" de la democracia (1983-1987)

interrupción del tránsito llevada a cabo por el Movimiento de Juventudes Políticas ${ }^{11}$ (MOJUPO). El motivo de la concentración obedecía al repudio a la presencia del banquero norteamericano David Rockefeller en Argentina. La nota, de un estilo político pletórico de sintagmas axiológicos peyorativos, tenía como fin alarmar a un paradestinatario lector sobre los "graves" desórdenes producidos en el centro de la ciudad de Buenos Aires, pues "revelan que los sectores más radicalizados de la izquierda política han decidido retomar el camino de la violencia y la provocación, que la abrumadora mayoría de los argentinos aspira a desterrar para siempre de sus prácticas políticas" (Otra vez la violencia en las calles, 1986). El señalamiento es esgrimido en nombre del ciudadano nacional, en este caso, argentinos, presentado como par antagónico de aquella minoría expresada como "sectores" cuya identidad es cuidadosamente omitida, a quienes adjudicaba el lugar de antidestinatarios del mensaje. Esta definición es reafirmada en otro pasaje de la nota, en el que explicaba mediante sintagmas axiológicos negativos: "La reaparición de métodos de acción directa de grupos ideológicos recalcitrantes. Esto significa un lamentable retroceso en el camino que la sociedad argentina ha emprendido hacia formas de convivencia pacíficas y hacia la plena vigencia de las instituciones democráticas" (Otra vez la violencia en las calles, 1986).

Otro recurso utilizado para estigmatizar a los jóvenes movilizados fue el discurso patológico, mecanismo que se concibe como un proceso de transferencia en el que una parte de la sociedad enferma puede contagiar al resto (Laclau, 2010, p. 53). En tal sentido, el diario postulaba la "reaparición de un sentimiento de temor e inseguridad en la opinión pública ante la posibilidad de que el virus de la violencia ${ }^{12}$ vuelva a ensombrecer la vida de los argentinos" (Otra vez la violencia en las calles, 1986).

El discurso del medio intentaba aislar a esa minoría violenta, presentándola como par antagónico no solo de la sociedad pacifista, sino también de aquellos miembros de los partidos políticos que participaron del evento. A estos últimos, si bien no los identificaba de manera particular, les recomendaba respetar las tradiciones de sus partidos y rechazar a los violentos, haciendo notar que resultaba penoso que agrupaciones políticas tradicionalmente identificadas con los métodos pacífi-
cos y la convivencia democrática apoyen y avalen a quienes pretenden volver a entronizar
la agresión irracional, la prepotencia y el desmán como formas aceptables de protesta o de
presión ideológica. (Otra vez la violencia en las calles, 1986)

\footnotetext{
${ }^{11}$ Este colectivo, en el cual estaban representadas tanto la oficialista juventud radical como las opositoras juventudes peronista, intransigente, comunista, demócrata cristiana, entre otras, tuvo sus orígenes en las movilizaciones contra la dictadura cuando acompañaron a las madres y abuelas de Plaza de Mayo en sus marchas, como también participaron de las concentraciones sindicales y de la Multipartidaria (Vommaro y Cozachcow, 2018).

12 Una interpretación original sobre este editorial de La Nación afirma que, en él, el matutino empleaba una doble estrategia discursiva personificando a quienes rechazaron la presencia de Rockefeller en la Argentina como un enemigo violento y peligroso, al tiempo que justificaba el accionar represivo de las fuerzas policiales (Casado, 2020).
} 


\title{
Austral Comunicación \\ Volumen 10, número 1 (junio de 2021): 321-347 ISSN (I) 2313-9129. ISSN (E) 2313-9137
}

Esta reflexión no solo tenía como paradestinatarios a los jóvenes militantes partidarios, sino también a la central obrera, que, a pesar de no haber participado en la marcha pues se encontraba concentrada en los preparativos del paro general que se produciría el 24 de enero siguiente, también recibiría la siguiente admonición: "Es lamentable que otros sectores de la vida nacional -como la Confederación General del Trabajo- aparezcan en una postura similar" (Otra vez la violencia en las calles, 1986). La razón del involucramiento de la CGT en esta controversia radicó, aunque el diario no lo precisó en su editorial, en un comunicado que la central obrera hizo público. ${ }^{13}$ La Nación continuó su editorial dirigiéndose al sector político y sindical para que se apartara del camino que ponía en riesgo la democracia, al afirmar que

\begin{abstract}
la legalidad democrática y del Estado de Derecho puede llegar a verse seriamente amenazada si las organizaciones de mayor predicamento en el campo político y gremial adoptan actitudes oportunistas y se niegan a asumir con claridad la responsabilidad que les corresponde en la lucha solidaria que la sociedad democrática argentina debe librar contra todo intento de reimplantar en el país la metodología de la violencia. (Otra vez la violencia en las calles, 1986)
\end{abstract}

En el cierre de la nota, mediante una serie de sintagmas axiológicos descalificantes, el diario señaló al Gobierno como prodestinatario de la falta de contundencia en su desaprobación a estos hechos, pues entendía que ser "tolerante con la subversión [...] sólo puede causar confusión, desasosiego y descreimiento respecto de las estructuras democráticas". Asimismo, apoyado en el principio de autoridad de la historia, le advertía al ciudadano nacional mediante una señalización imperativa:

\begin{abstract}
Nadie tiene derecho a olvidar el alto precio que la Nación pagó en el pasado por no haber contenido a tiempo las acciones de los grupos interesados en propagar la violencia y el caos. La sociedad argentina debe unirse solidariamente en la defensa de la legalidad democrática para aislar a los provocadores - cualquiera que sea su signo ideológico- que pretendan socavar sus bases. (Otra vez la violencia en las calles, 1986)
\end{abstract}

Esta preocupación sobre un rebrote "subversivo" también la haría notar poco tiempo después, cuando centrara su lupa sobre el prolongado conflicto sindical protago-

\footnotetext{
${ }_{13}$ El diario aquí examinado había publicado en la sección informativa: "La CGT manifestó ayer 'su profunda alarma por la reparición (sic) de métodos represivos que se han ejercido contra jóvenes argentinos que intentaban manifestar sus opiniones relativasa (sic) un banquero extranjero, financista del Proceso y comprometido con lo que hoy constituye uno de los problemas más acuciantes que padece todo el pueblo argentino con el tratamiento de la pretendida deuda externa. La central obrera difundió un documento con estas expresiones, al término de una reunión de su consejo directivo" (Acusan al Gobierno por los disturbios..., 1986). Cabe mencionar que el señalamiento cegetista sobre la deuda externa tenía como antecedente la definición incluida en el Plan de 26 Puntos dado a conocer en el acto celebrado el día del tercer paro general durante el Gobierno alfonsinista, el 29 de agosto de 1985. Allí reclamaba una "moratoria para el pago de servicios de la pretendida deuda externa", como también "someter al Congreso Nacional, como establece la Constitución, la decisión sobre la naturaleza y legitimidad de la pretendida deuda externa". Además, Rockefeller era directivo del Chase Manhattan Bank, entidad líder de la banca norteamericana y artífice del sistema financiero internacional. Sobre el rechazo del diario al Plan cegetista, puede consultarse Díaz y Giménez (2018b).
} 
César Luis Díaz, Mario Jorge Giménez

El diario La Nación versus el sindicalismo argentino. La construcción de un enemigo "subversivo" de la democracia (1983-1987)

nizado por los conductores de colectivos en la ciudad de Córdoba. Allí, mediante un discurso jurídico, sentenciaba que organizar un piquete en el centro de la capital cordobesa constituía el delito de "Peligrosa tendencia hacia la sedición" (Agitación gremial permanente, 1986). Conducta que si bien no estaba penada en el Código Penal (s/f) reformado en democracia, era punible según el Código de Faltas de la provincia de Córdoba, aprobado durante la dictadura vigente en el momento que aquí se examina.

El matutino, con similar estilo discursivo, le marcaba al lector, a través de sintagmas axiológicos negativos, que los activistas llevaron a cabo un

\begin{abstract}
ejercicio anárquico y fuera de todo cumplimiento de las reglamentaciones respectivas, del derecho de huelga. Impiden a quienes no piensan como ellos, el derecho correlativo al trabajo y utilizan sin titubeos la agresión armada para doblegar las voluntades que se les oponen. Para perfeccionar la acción, bandas diversas depredaron comercios y provocaron pánico y corridas entre la población. (Agitación gremial permanente, 1986)
\end{abstract}

Además de los acontecimientos acaecidos en Córdoba, agregó que "con escasa diferencia de tiempo declararon medidas de fuerza de variado alcance trabajadores del transporte (aéreo, ferroviario, automotor y subterráneo), telepostales, bancarios, médicos, judiciales, recolectores de residuos, etc.", cuya sincronía de sucesos le permitió a $L a$ Nación titular con tono alarmista: "Agitación gremial permanente" (1986).

Las medidas de fuerza continuaron transparentándose en otro editorial cuyo título denotativo expresaba "Córdoba paralizada" (1986). Luego de exponer su crítica al prolongado paro de choferes -cuatro días-, puntualizaba al paradestinatario lector que la "agitación y violencia se adueñó del centro de la ciudad" (Córdoba paralizada, 1986). Seguidamente, catalogaba como delincuencial la conducta de los sindicalistas con un discurso jurídico que fustigaba la "interrupción del tránsito" (Córdoba parali$z a d a, 1986)$.

Todos estos hechos, según la óptica editorial de La Nación, configuraban una "actitud sediciosa" que "nada tienen de improvisado o espontáneo" (Córdoba paralizada, 1986). Indudablemente, esta retórica articulaba conceptos tendientes a producir un impacto en sus lectores. Además, el medio condenaba, mediante un discurso patológico, la apelación a "recursos reñidos con la convivencia civilizada impropio de la vida en democracia" (Córdoba paralizada, 1986). Esa retórica civilizatoria (Steimberg, 2000, p. 238) sería complementada con el recurso del par antagónico con el fin de proponer la figura del sindicalismo como la representación de la barbarie que contrastaba con una sociedad civilizada. En este caso, permite evocar las afirmaciones vertidas por los estudiosos de las multitudes a fines del siglo XIX, que las consideraban incapaces de tener pensamiento racional, las asimilaban a los salvajes y por ello cualquier tipo de reunión colectiva era sistemáticamente degradada (Laclau, 2010, p. 61). 


\section{Austral Comunicación \\ Volumen 10, número 1 (junio de 2021): 321-347 ISSN (I) 2313-9129. ISSN (E) 2313-9137}

El diario, además de señalar a esta minoría agresiva como "un sector -sólo un sector- que trata de imponer por la violencia sus puntos de vista y nos pone más lejos de los objetivos de una sociedad que aspira a convivir armoniosamente", también advertía, basado en el principio de autoridad de la historia, que este camino de confrontación implicaba "retornar a prácticas que ensangrentaron a la Nación" (Córdoba paralizada, 1986). Al tiempo que se interpelaba retóricamente si sus promotores estaban "interesados en fomentar, con episodios de esta naturaleza, una nueva alternativa militar" (Córdoba paralizada, 1986), respondía de manera sentenciosa: “Para muchos, los graves incidentes de las calles de Córdoba evocaron los días de $1969^{14}$ que marcaron el comienzo de toda una década de violencia subversiva con secuelas que todavía no han cicatrizado" (Córdoba paralizada, 1986).

En torno a otro actor político de relevancia en esa época, Córdoba se constituiría en escenario de un acontecimiento de violencia. Nos referimos al hallazgo de un artefacto explosivo, el 19 de mayo de 1986, en una alcantarilla del interior de la sede del Tercer Cuerpo de Ejército en el trayecto previsto para el paso del presidente Alfonsín en su visita a la unidad militar. El conmocionante suceso ocupó y preocupó al diario, que, sin embargo, editorializó recién unos días después bajo el título "El episodio del III Cuerpo de Ejército" (1986). La nota eludía referir la tentativa de magnicidio, condenando el hecho como un "intento al menos, de demostrar la voluntad" (El episodio del III Cuerpo de Ejército, 1986) de atentar contra la vida del presidente. Por su estilo, resulta imposible de encuadrar en los señalados por Rodrigo Alsina (1991), aunque se debe destacar que enfatizaba la celeridad del comandante de ese cuerpo en dimitir como "una actitud que vale la pena señalar y que sería injusto dejar pasar en silencio" (El episodio del III Cuerpo de Ejército, 1986). Y si bien eludió mencionarlo como una acción desestabilizadora de la democracia, reconocía que de haberse producido hubiera implicado "una tragedia de gravísimas consecuencias", encargándose de aclarar la inutilidad del arma utilizada al corroborarse que "carecía del equipamiento indispensable para funcionar" (El episodio del III Cuerpo de Ejército, 1986).

El mensaje editorial finalizaba con la formulación del par antagónico que confrontaba al ciudadano nacional con una minoría innominada, la "unanimidad en la Argentina de hoy, si descartamos a grupos minúsculos que, desde los extremos ideológicos sólo animados por afanes totalitarios y violentos, jamás han querido ni la democracia ni la libertad ni el Estado de Derecho" (El episodio del III Cuerpo de Ejército, 1986).

\footnotetext{
${ }_{14}$ Seguramente se refería a las jornadas suscitadas a partir del 29 de mayo de 1969, cuando una movilización obreroestudiantil denominada periodísticamente como "Cordobazo" puso en jaque al Gobierno de facto encabezado por el general Juan Carlos Onganía. Puede consultarse en Gordillo (2019).
} 
César Luis Díaz, Mario Jorge Giménez

El diario La Nación versus el sindicalismo argentino. La construcción de un enemigo "subversivo" de la democracia (1983-1987)

Además de las prácticas sindicales centradas en la capital cordobesa, el matutino cuestionó tanto la medida de fuerza que paralizó al país como el acto organizado por la CGT. Esta misma actitud la había sostenido en los días previos a la huelga general del 24 de enero de 1986, cuando criticó la solidaridad de la central obrera con los jóvenes reprimidos en su repudio a Rockefeller. Mediante un discurso político, después de afirmar que los dirigentes sabían "sin asomo de duda" que no lograrían la mejora salarial reclamada, refirió que era "un paro político" y, por ende, "incomprensibles, en plena vigencia de la democracia, cuando funcionan los organismos constitucionales encargados de gobernar" (El paro general, 1986).

El diario indicaba el carácter "fascista" del evento valiéndose de sintagmas axiológicos negativos, y también fustigaba la presencia de militantes del comunismo, considerando a los sectores participantes como expresiones de "los grandes movimientos totalitarios de este siglo" (El paro general, 1986). Similares sintagmas utilizó para repudiar la presencia de los miembros de un sector interno del justicialismo: El "peronismo revolucionario -denominación que encubre apenas a los viejos militantes del terrorismo montonero- ${ }^{15}[\ldots]$ Todos los hechos sucedidos después en la Argentina no parecen haber bastado para que esos grupos hayan abandonado definitivamente sus viejos métodos" (El paro general, 1986). De este modo, el centenario matutino seguía apelando al principio de autoridad de la historia previa al golpe de 1976, para alertar, en este caso, sobre el resurgimiento de una de las organizaciones armadas que actuaron durante la década del $70 \mathrm{y}$, por ende, la posibilidad de que la democracia se encontrara en vísperas de otra interrupción institucional, como la ocurrida diez años antes.

En el mes de abril, cuando los conductores de taxímetros decidieron imitar a los choferes de colectivos en su modalidad de reclamo, el diario retomó la autorreferencialidad y la apelación al discurso patológico para confrontar con el movimiento obrero, expresando:

Como dijimos ya anteriormente, no es exagerado sostener que este tipo de bloqueos constituye un verdadero entrenamiento subversivo al cual es arrastrada, probablemente sin comprender del todo la naturaleza de la acción, la mayoría de quienes toman parte en su desarrollo. (Bloqueo de calles en la ciudad, 1986)

Personas a las que concebía como carentes de raciocinio y víctimas inermes del proceso de transferencia en el que esa parte de la sociedad enferma podía contagiar al resto (Laclau, 2010, p. 53). La Nación entendía que la medida de fuerza ostentaba

\footnotetext{
${ }_{15}$ Motoneros fue una organización política armada que perteneció al movimiento peronista. Iniciaron su actuación con el secuestro del general Pedro Eugenio Aramburu el 29 de mayo de 1970, pasaron a la clandestinidad en democracia en una conferencia de prensa el 6 de septiembre de 1974 y enfrentaron abiertamente al Gobierno de Isabel Perón. Durante la dictadura, desde el exilio, intentaron infructuosamente dos reingresos al país. Puede consultarse en Gillespie (1987).
} 
carácter golpista y por ello remarcaba que "la democracia no se sostiene con actitudes como la comentada. Antes bien, son esas actitudes las que la socavan y abren el camino a los gobiernos autoritarios" (Bloqueo de calles en la ciudad, 1986). Por ello se dirigía al Gobierno como paradestinatario, intimándolo a que adoptara las medidas necesarias para combatir a los subversivos en defensa de la institucionalidad y evitar, en definitiva, la repetición de lo ocurrido una década antes: un golpe de Estado. Resulta ostensible que La Nación construía un particular mensaje en defensa de la democracia, que sería la "proclamación de la superioridad del interés colectivo o nacional", denunciando el accionar de un "particularismo" que asumía dos formas concretas de "facción" y de "corporación" (Bobbio, 2010, p. 148), en este caso, encarnadas en el sindicalismo.

La pertinaz pluma editorial del matutino no les otorgó tregua a los dirigentes gremiales. Por ejemplo, ante un prolongado conflicto protagonizado por los trabajadores de los servicios eléctricos afiliados al gremio de Luz y Fuerza en el área metropolitana (Capital Federal y Gran Buenos Aires) durante mayo de 1986, destinó una serie de notas. En dos de ellas, no dudó en reiterar las imputaciones antes aplicadas a los militantes de otros sectores del quehacer laboral. El diario apelaba no solo al discurso civilizatorio, sino también a la figura de la personificación, con el objeto de explicar que a ese servicio "la civilización de nuestro tiempo lo ha convertido, en efecto, en una necesidad imperiosa para la vida" (Los paros y el suministro eléctrico, 1986). Por ende, quienes limitaban el acceso a ese servicio vital actuaban de manera incivilizada o antisocial.

La Nación consideraba que la medida constituía "un acto de naturaleza subversiva que, convenientemente extendido, alcanzaría un poder extraordinario" (Los paros y el suministro eléctrico, 1986). Por ello, para garantizar la estabilidad institucional, volvió a reclamarle al Gobierno como paradestinatario que utilizara los instrumentos del Estado a su disposición. Cuando se apercibió que los afiliados al sindicato de la electricidad volverían a llevar a cabo medidas de fuerza, dada la entidad sediciosa que les asignaba el matutino, emplazaría al Poder Ejecutivo haciendo notar que "el Gobierno está obligado a implementar leyes en defensa de la sociedad. En caso contrario esa sociedad quedaría en desamparo legal, frente a un ataque a las bases mismas de la vida cotidiana" (Los servicios eléctricos, 1986). Además, volvió a apelar al ciudadano nacional, confrontándolo mediante un par antagónico con los sindicalistas, a quienes les recriminaba que "el país realiza un gran esfuerzo para controlar la inflación y que ese esfuerzo impone sacrificios no deseados, pero necesarios. Los únicos aumentos [salariales] no inflacionarios provienen de la mayor productividad y de la racionalización de los servicios" (Los servicios eléctricos, 1986). Con la finalidad de conferir mayor dramatismo a su tipificación de la medida de fuerza como subversiva, empleó el recurso de la analogía, mediante el cual destacaba las semejanzas de este comportamiento con lo sucedido durante el tercer Gobierno peronista, pues "los resultados de 
César Luis Díaz, Mario Jorge Giménez

El diario La Nación versus el sindicalismo argentino. La construcción de un enemigo "subversivo" de la democracia (1983-1987)

la acción sindical en algunos de estos sectores ya fueron experimentados en el aciago período de 1973 a 1976, situación que desembocó en un desorden social e institucional generalizado" (Los servicios eléctricos, 1986).

Durante el conflicto protagonizado por el gremio de Luz y Fuerza, ante el anuncio de medidas similares por parte de los dirigentes del gremio telepostal, el diario explicó que ese comportamiento no constituía un caso aislado, sino que formaba parte de una escalada de conflictos. Si bien aclaraba que la paralización del correo "no pondrá en crisis al país de manera inmediata" (Un nuevo conflicto en el Correo, 1986), advertía que si se prolongaba como el de los trabajadores del servicio eléctrico, podía

llegarse a un punto en que se produzca un estado de conmoción total del sistema, con una
secuela casi inimaginable de desórdenes en una serie de actividades que se caracterizan,
justamente, por mantener estable no solamente el campo de la producción y del trabajo en
general sino el conjunto de las relaciones humanas. (Un nuevo conflicto en el Correo, 1986)

De modo que si bien no denunció que la huelga tenía intenciones golpistas, señaló, con una retórica civilizatoria, que esa acción no solo afectaba las bases económicas, sino además la vida civilizada de la nación. En definitiva, el matutino sostuvo una prédica que no aceptaba estas medidas de fuerza como expresión de demandas democráticas y, por esa razón, negaba el legítimo derecho a huelga de los trabajadores, desconociendo su valor como método para procesar conflictos (Przeworski, 2010, p. 65).

\section{La Nación y sus dispares miradas sobre la violencia política}

Durante la segunda mitad de 1986 y la primera de 1987, La Nación no asoció el comportamiento sindical con el golpismo. Esto no implicaba que el movimiento obrero organizado hubiera cesado en el sostenimiento de medidas de fuerza reivindicativas por sector y en concretar paros generales que confrontaban con el plan económico del Gobierno, tampoco que el matutino no los hubiera condenado con firmeza. Así lo hizo notar al cumplirse el primer aniversario de la puesta en marcha del Plan Austral, ${ }^{16}$ cuando, en nombre de la defensa de la democracia, impugnó la huelga general del 12 de junio mediante conceptos propios del discurso civilizatorio, que le atribuían al gremialismo argentino un comportamiento atávico. Análoga modalidad adoptó con la

\footnotetext{
${ }_{16}$ Frenkel y Fanelli (1986) afirman que "el Plan Austral puede interpretarse como una estrategia de avance en varios frentes simultáneos intentando evitar las inconsistencias que habían inducido los planes anteriores al implementarse ajustes parciales. De aquí que todas las medidas que conforman el programa están íntimamente relacionadas y no resulta aconsejable analizarlas por separado sin tener en cuenta permanentemente las interacciones esperadas entre ellas. Los pilares básicos que dan sustento al programa se pueden resumir en: a) congelamiento de precios, salarios, tipo de cambio y tarifas públicas; b) ajuste de las cuentas fiscales y renegociación de los compromisos de la deuda externa; c) reforma monetaria” (p. 20). Por su parte, Rapoport (2003) considera que el plan puesto en vigencia en junio de 1985 constituía un plan "económico 'heterodoxo' [que] implicó un ajuste fuerte, aun mayor que lo solicitado por el FMI, con el objetivo explícito de evitar el peligro de una hiperinflación” (p.911).
} 


\section{Austral Comunicación \\ Volumen 10, número 1 (junio de 2021): 321-347 ISSN (I) 2313-9129. ISSN (E) 2313-9137}

medida de fuerza ejecutada el 9 de octubre de 1986 (El ejercicio racional de la huelga, 1986).

El diario, que había demostrado una perseverancia sistemática en auscultar al actor sindical en los momentos de conflictividad, omitió editorializar acerca de la regularización legal de la CGT. El 7 de noviembre de 1986 se llevó a cabo la elección de las autoridades legitimadas por la previa normalización de cada uno de los gremios que la integraban (el "ubaldinismo", "los renovadores" de la ex "comisión de los 25 " y los "ortodoxos" de las 62 organizaciones) ${ }^{17}$ quienes, además de consagrar su unidad, demostraron que el predominio de los referentes vinculados con el peronismo seguía intacto. $^{18}$

Este avance de la dirigencia gremial no implicó ninguna tregua en el nivel de conflictividad que se incrementaba, así como menguaba la calidad de vida que los trabajadores heredaron de la dictadura cívico-militar. Además, en 1986, el índice de desocupación tuvo un pico histórico, pues pasó del 6 al 12\% (Iñigo Carrera, 2001, pp. 3-4), mientras que el costo de vida "creció un 82\%" (Ferrer, 2004, p. 316).

El año entrante no mostró un perfil sindical distinto, como quedó evidenciado el 26 de enero de 1987 cuando la central obrera produjo el cuarto paro general del bienio examinado en este apartado, también fustigado por La Nación, en este caso, en defensa del ministro de Economía y su plan ${ }^{19}$ (La teoría del hombre malo, 1987). El Gobierno, a partir de febrero de ese año, encaró una nueva etapa del plan económico mediante otro congelamiento de precios y un reajuste salarial, además de una suba de las tarifas públicas y del combustible y una mayor integración al comercio internacional a través de una apertura exportadora. En el plano político, el alfonsinismo, con el propósito de debilitar al sindicalismo, acompañó las disposiciones económicas con la incorporación como ministro de Trabajo del dirigente peronista Carlos Alderete, del gremio de Luz y Fuerza y miembro del recientemente creado grupo de los "15", "expresión laboral de los procesos de reestructuración económica y afianzamiento de los espacios de acumulación del capital concentrado local en colusión con el Estado" (Aruguete, 2006, p. 444). Constituía una suerte de élite sindical que actuaba al margen de los estamentos orgánicos de la central obrera, tal como lo hacían los empresarios identificados como

\footnotetext{
17 El Consejo Directivo de la CGT fue ampliado de 20 a 21 miembros. "De los 21 cargos que constituyeron dicho cuerpo, el acuerdo logrado permitió colocar 6 miembros de cada uno de los sectores, a los que se agregaron -además de Ubaldini en la Secretaría General- un radical y un peronista independiente cercano a la ortodoxia" (Gaudio y Thompson, 1990, p. 161).

${ }^{18}$ Senén González y Bosoer (1993) señalan que "de los 1.478 delegados al congreso normalizador, representantes de cuatro millones de trabajadores sindicalizados y 156 sindicatos, un $80 \%$ se identifica con el peronismo en sus distintas variantes" (p. 75).

19 El responsable de la línea editorial del matutino, Claudio Escribano, afirmaría tres décadas después: "El Plan Austral fue una bocanada de oxígeno, una corrección de la política que estaba en vigor, con un ministro de Economía con quien no he cambiado más que saludos ceremoniosos en alguna reunión social y en la calle, pero por quien tengo una suerte de admiración, que es Juan Sourrouille" (Caligaris y Ezcurra, 2021, p. 262).
} 
César Luis Díaz, Mario Jorge Giménez

El diario La Nación versus el sindicalismo argentino. La construcción de un enemigo "subversivo" de la democracia (1983-1987)

"capitanes de la industria", ${ }^{20}$ que establecían vínculos con otros actores políticos y apoyaban el plan económico por fuera de la Unión Industrial Argentina (UIA), a la que pertenecían.

La designación del gremialista sería duramente cuestionada por el diario, ya que la consideraba el resultado de una suerte de entente radical-peronista. El paso de Alderete por el gobierno no contribuyó a la concertación que anhelaba el radicalismo, pues convirtió su cartera en una trinchera contra la de economía, al tiempo que legitimó una grieta en el actor sindical debilitando la unidad de la cúpula cegetista alcanzada en noviembre de 1986. La concertación consiguió la suspensión de huelgas generales entre marzo y septiembre, aunque no logró hacer lo propio con los paros sectoriales y las concentraciones callejeras, que continuaron con el ritmo anterior a su breve participación en el Gobierno nacional. El ministro de Trabajo renunció después de las elecciones a gobernadores del 6 de septiembre de 1987 ante el triunfo del peronismo en casi todas las provincias (el radicalismo solo ganó en una, mientras que partidos provinciales lo hicieron en dos).

El sindicalismo, por su parte, continuó con sus reclamos, que, en los últimos tres meses del año, producirían veintitrés medidas de fuerza (Ferraresi y Galasso, 2018, p. 252). Las huelgas fueron sectoriales, además de dos paros generales: el 4 de noviembre (no examinado por La Nación en su columna editorial) y el de las jornadas del 8 y 9 de diciembre de 1987. En este caso, ofreció una nueva columna crítica en la que destacó la relevancia del acto electoral, presentándolo como par antagónico de la medida de fuerza encarada por la CGT. Por ello, señalaba que "así como la renovación democrática de mandatarios y legisladores es una muestra de avance de la cultura política argentina, la decisión de la central obrera representa una actitud y una visión detenida en el tiempo" (Nuevos gobernadores y el paro de la CGT, 1987), demostrando con su afirmación una recurrencia a la retórica civilizatoria para confrontar con el actor político sindical.

Luego del sumario repaso de la situación del movimiento obrero durante 1987, se debe anotar que, a mediados de ese año, el país volvió a conmoverse por un acontecimiento que el matutino tituló "La metodología de las bombas" (1987). La nota, basada en la colocación de dieciséis explosivos en otros tantos comités radicales, le permitió aseverar que el ciudadano nacional se encontraba en presencia de una anónima "organización en condiciones de retomar la violencia como metodología de acción política" (La metodología de las bombas, 1987). El diario manifestaba que "hablar de "ultraizquierdas" o "ultraderechas" parecería ser, a esta altura, un ejercicio dialéctico intrascendente" (La metodología de las bombas, 1987). Si bien intentaba sustraerse de esclarecer a quién le correspondía la responsabilidad de los atentados y cuáles eran sus objetivos

${ }_{20}$ Azpiazu et al.(2004) denominan “¿capitanes de la industria o generales de la economía?” (p. 12) a quienes alcanzaron un sitial de preponderancia en el seno del empresariado local desde los años de la última dictadura cívico-militar. 


\section{Austral Comunicación \\ Volumen 10, número 1 (junio de 2021): 321-347 ISSN (I) 2313-9129. ISSN (E) 2313-9137}

políticos, igual conjeturaba que su "meta principal bien puede ser provocar una sensación de temor y de confusión en la opinión pública, lo cual la identificaría con la finalidad esencial de los movimientos subversivos en todo el mundo" (La metodología de las bombas, 1987). De este modo, dirigiéndose a sus lectores como paradestinatarios, centraba su atención en quienes hasta el momento se habían vinculado con un comportamiento subversivo: el peronismo revolucionario, sectores del sindicalismo y el Partido Comunista. Para robustecer esta construcción de sentido, relacionaba la sincronía de estos actos de terrorismo con la puesta en vigencia de la ley de obediencia debida ${ }^{21}$ que favorecía la impunidad de los militares subalternos que cometieron delitos de lesa humanidad durante la dictadura cívico-militar. Los atentados ocurrieron "inmediatamente después de que la Corte declarara la constitucionalidad de aquélla [la obediencia debida que], permite relacionar ambas circunstancias y alienta sospechas sobre la orientación política de los responsables" (La metodología de las bombas, 1987).

De este modo, La Nación ampliaba el universo de imputados, pues a la vigencia de esa ley se habían opuesto todos los organismos defensores de los derechos humanos, las madres y abuelas de Plaza de Mayo, los miembros juveniles de un importante número de partidos políticos argentinos enrolados en el MOJUPO, los partidos políticos de la izquierda que se expresaron orgánicamente, como también a sectores internos de los partidos mayoritarios, el peronismo e inclusive del propio radicalismo, quienes, además, tampoco dudaron en manifestar su rechazo al hecho que motivó el editorial.

El diario, para reafirmar la estrategia comunicacional en defensa de la institucionalidad, se dirigió al país, a quien le reclamaba que "condene unánimemente el renacer de la violencia [para contribuir con la consolidación de la] democracia, de la convivencia pacífica y del diálogo civilizado como regla de la vida política" (La metodología de las bombas, 1987). En paralelo, presentaba como par antagónico al agrupamiento conformado por los anónimos colocadores de artefactos explosivos en comités radicales, los identificados oficiales del ejército que se sublevaron contra la República violando la Constitución Nacional e incluso sumó a la nómina de sediciosos al sindicalismo, sentenciando con un discurso político:

\footnotetext{
$\mathrm{Ni}$ asonadas o amotinamientos, ni avances corporativistas disfrazados de exigencias sindicales, ni bombas o atentados caben ya en la República. El funcionamiento correcto de las instituciones y la vigencia de la ley y el orden son la única alternativa para el futuro. ( $\mathrm{Ca}$ metodología de las bombas, 1987)
}

\footnotetext{
${ }^{21}$ La Ley 23521, sancionada el 8 de junio de 1987, establecía que los delitos cometidos por militares que tuvieran rango inferior a coronel durante la dictadura cívico-militar no eran punibles, pues se limitaron a obedecer a sus superiores. Esta ley fue resultado de la rebelión de los militares "carapintadas", que se alzaron contra la democracia en la Semana Santa de 1987; la lograron en la negociación con Alfonsín a cambio de deponer su actitud.
} 
Así, eludía vincular el levantamiento militar contra el orden constitucional durante la Semana Santa de $1987^{22}$ con la denuncia presidencial sobre la existencia de conspiraciones golpistas por parte de ciertos uniformados, previa a ese acontecimiento. De este modo, el matutino se dirigió a la opinión pública alertando que no se dejara persuadir por "quienes persiguen intereses contrarios a la defensa de las instituciones republicanas aunque solapadamente se cobijen, de momento, detrás de esas banderas" (Afirmación del régimen constitucional, 1987), en obvia alusión a los sectores juveniles que se habían movilizado para defender la estabilidad democrática durante esa Semana Santa, como antes lo habían hecho para repudiar la presencia de Rockefeller en la Argentina.

Un dato importante para ponderar la actitud de la central obrera es que unos días antes del intento golpista de los "carapintadas" liderados por el teniente coronel Aldo Rico, la CGT había firmado junto a los partidos políticos, la UIA y el Gobierno un

compromiso democrático ante la situación de rebeldía y amenaza al orden constitucional. Se reiteraba allí la firme e irrevocable decisión de apoyar con todas las acciones a su alcance la vigencia irrestricta de la Constitución Nacional, del normal desenvolvimiento de las instituciones del Estado, y de la democracia como único estilo de vida para los argentinos. (García Lerena, 2007, p. 264)

\section{La construcción periodística de un actor antirrepublicano}

Como se ha expresado, La Nación tenía una alta valoración inicial de la gestión de Alfonsín. Consideraba que podía constituirse en un clivaje en el sistema político argentino, inaugurando una nueva institucionalidad liberal. Ese punto de inflexión se inspiraba en la división y el funcionamiento de los tres poderes de acuerdo a lo establecido por la Constitución Nacional, pues era la única opción viable para consolidar la democracia. Esta convicción ubicaba al diario como un fuerte contendor de la democracia de masas, que en la Argentina reconocía como antecedentes las experiencias yrigoyenistas (1916-1922 y 1928-1930) y peronistas (1946-1955 y 1973-1976), pues percibía

la cuestión de la democracia como ligada al marco simbólico liberal, identificándola implícitamente con la democracia liberal [y negando legitimidad a] la tradición democrática, cuyas ideas principales son las de igualdad en la que la cuestión de la constitución de una subjetividad popular se convierte en una parte integral de la cuestión de la democracia. (Laclau, 2010, p. 211)

El sindicalismo, que había soportado el rigor represivo de la dictadura desarrollando distintas estrategias de supervivencia en la clandestinidad, se convirtió tam-

\footnotetext{
${ }^{22}$ Un interesante análisis sobre la actuación de un órgano gráfico afín a los protagonistas de este acontecimiento puede encontrarse en Saborido y Borrelli (2014).
} 


\section{Austral @municación \\ Volumen 10, número 1 (junio de 2021): 321-347 ISSN (I) 2313-9129. ISSN (E) 2313-9137}

bién en un actor relevante en la construcción de la democracia que los argentinos recuperamos en 1983. A partir de entonces, su activo protagonismo durante el bienio 1984-1985 había sido descalificado por el matutino, que rechazaba sus acciones como exhibición de un "poder sindical" (Díaz y Giménez, 2018b) contrario a los preceptos liberales de la Constitución. En este periodo, La Nación elaboró un discurso en el que concebía ciertas prácticas gremiales como "subversivas" y, en consecuencia, advertía que, de mantenerse, el país podría enfrentarse nuevamente a un golpe de Estado. También denunció que este actor político tenía la intención de desvirtuar el sistema democrático pretendiendo sojuzgar a los tres poderes de la República.

Por ejemplo, ante el reclamo de los trabajadores del Poder Judicial para mejorar sus haberes, daba cuenta de que el gremio "amenazaba" con adoptar medidas de fuerza de una magnitud inaceptable, a punto tal que "prácticamente no se podrá trabajar en la Justicia durante 1986" (Agitación gremial permanente, 1986). Para construir una imagen conspiradora del sindicalismo se apoyaba en sintagmas axiológicos peyorativos, mediante los cuales se dirigía a un paradestinatario tácito al sugerir que este comportamiento obedecía a la tolerancia que se le dispensaba a un sindicalismo que "con total impunidad, anuncia sin ocultamientos que el sistema tripartito de poderes constitucionales quedará mutilado con el objeto de resolver un problema salarial" (Agitación gremial permanente, 1986). Tras este cuestionamiento, predecía que si se consumaba la comisión del delito y no se sancionaban a los autores, podría ser imitado por los trabajadores de otras dependencias públicas y "por idénticas razones, mañana podría impedirse el funcionamiento del Congreso o del Poder Ejecutivo" (Agitación gremial permanente, 1986).

No transcurrió mucho tiempo para que la predicción quedara confirmada, pues resulta altamente probable que, al momento de escribirse la columna sobre el conflicto de los judiciales, La Nación estuviera al tanto de una reunión celebrada entre dirigentes obreros y empresarios en la ciudad de Buenos Aires, a la cual los dirigentes de la CGT y de la UIA denominaron “Congreso de la Unidad Nacional”. De aquí que, al día siguiente, publicara un editorial criticando este encuentro, que tuvo por resultado la elaboración de un programa económico de corte industrialista presentado públicamente el 12 de febrero de 1986, al cual el diario consideraba un mecanismo de presión inadmisible contra los poderes Ejecutivo y Legislativo de la nación.

Se debe mencionar que este evento tuvo lugar después de cuatro fracasos en otras tantas convocatorias a la "concertación" efectuadas por el Poder Ejecutivo para dialogar con ambos actores. La imposibilidad de esos encuentros seguramente obedeció a la intransigencia cegetista en sus demandas, como también a la estrategia del Gobierno de privilegiar el vínculo directo con las élites empresariales y obreras y no con sus representantes orgánicos. 
César Luis Díaz, Mario Jorge Giménez

El diario La Nación versus el sindicalismo argentino. La construcción de un enemigo "subversivo" de la democracia (1983-1987)

Sin duda, los ribetes que había adoptado la invitación de la dirigencia obrera a la empresaria a "elaborar una política socioeconómica de alternativa" (Entre la concertación y las instituciones, 1986) produjo la reacción del diario, que, en medio de tanta conflictividad, lejos de valorarlo como un accionar democrático propositivo que legitimaba a estos representantes como actores fundamentales de la economía y de la producción, lo rechazaba por constituir un ejercicio antiparlamentario. Así, con un discurso jurídico, ubicaba en la ilegalidad a ese consenso, pues, de los temas abordados, "casi la totalidad de sus puntos eran cuestiones propias de tratamiento parlamentario legislativo [...] con lo que se trataba de condicionar, apelando a decisiones corporativas, el papel del Congreso" (Entre la concertación y las instituciones, 1986). Mediante similar estilo discursivo consideró este accionar como destituyente, pues afectaba a Alfonsín en sus atribuciones indelegables, destacando "la extraordinaria gravedad que un acto de esa naturaleza -elaborar sectorialmente un plan de gobierno y tratar de imponerlo coactivamente al Poder Ejecutivo- tiene para la estabilidad del sistema" (Entre la concertación y las instituciones, 1986).

Líneas más adelante recurrió a un enunciado construido por sintagmas axiológicos negativos destinados a descalificar este comportamiento por constituir formas "corporativas" y "residuos de los tiempos de autoritarismo". Además, basándose en el principio de autoridad que emana de la Carta Magna, objetaba a los sindicalistas la pretensión de "suplantar al régimen republicano representativo y democrático por caer en alguna de las figuras sediciosas que repudia la Constitución" (Entre la concertación y las instituciones, 1986). El diario diferenciaba este proceder con la legitimidad del derecho de petición que se encontraba vigente, conminando a la CGT a limitar los reclamos a "sus intereses sectoriales, [pues] respetar esas vías legítimas es aceptar la democracia como sistema de convivencia política. Eludirlas compulsivamente es una manera de socavar la estabilidad de las instituciones republicanas y democráticas de la Constitución" (Entre la concertación y las instituciones, 1986). De esta manera, sugería que cualquier modalidad de protagonismo adoptada por este actor político, en lugar de reafirmar su compromiso democrático, se convertía en violatorio de la Constitución Nacional.

Por último, destacaremos que luego del intento inicial del Gobierno alfonsinista de impulsar una Ley de Asociaciones Profesionales, que produjo cambios en la organización sindical, se presentó dos años y medio después otro proyecto de ley en el parlamento argentino. En este caso, La Nación volvió a criticar las aspiraciones de los dirigentes sindicales apelando a su capacidad de gravitación en la opinión pública con el fin de lograr una ley complaciente con sus ideas. Por ello, mediante un discurso político orientado al lector paradestinatario, retomaba la figura de la analogía para comparar la actitud de los sindicatos de ese momento con la que sus pares habían sostenido durante la etapa previa al golpe que destituyó al último Gobierno peronista. Los diri- 


\section{Austral@municación \\ Volumen 10, número 1 (junio de 2021): 321-347 ISSN (I) 2313-9129. ISSN (E) 2313-9137}

gentes de la CGT solo atinaron a "rechazar de plano toda transformación y en pedir, inclusive, un retorno irrestricto al 'status' preexistente al gobierno militar de 1976, que [demostró] ser también parte de las causas que llevaron a la crisis a la administración constitucional de entonces" (La reforma laboral y el Congreso, 1986). De este modo, enfatizó en la recurrencia del sindicalismo a incursionar en conductas contrarias a la estabilidad democrática del país.

\section{A modo de conclusión}

Durante el periodo examinado, La Nación, en su carácter de actor político, especuló con que la derrota electoral del peronismo en 1983 favorecería la recreación de una tradición político-institucional liberal, inspirada en la Constitución Nacional, similar a la vigente entre 1853 y 1916. Para lograr ese cometido, interpeló recurrentemente al Gobierno nacional como paradestinatario y al sindicalismo como antidestinatario. En este punto, conviene señalar una excepción en la que lo trató como paradestinatario por no haber participado de una movilización, y solo haber manifestado su solidaridad con los jóvenes reprimidos durante el acto de repudio a la presencia de Rockefeller en la Argentina.

El matutino, fiel representante de sectores tradicionales de la burguesía agroexportadora, cuestionó ciertas particularidades de la democracia de masas del siglo XX, en este caso, las demandas de las organizaciones sindicales, en coincidencia con las de ciertos partidos políticos o las de sus jóvenes militantes. Las luchas sindicales fueron estigmatizadas con el uso alternado de un discurso jurídico, político, patológico y, en una ocasión, militar. En efecto, la retórica, profusamente poblada de sintagmas axiológicos peyorativos, formaba parte de un mensaje orientado a producir en los lectores un sentido de vigilia permanente, con el propósito de consolidar el par antagónico de una mayoría que defendía el orden liberal vigente, en contra de una minoría subversiva que atentaba contra él. En ese sentido, era usual que el diario se arrogara ser el vocero del ciudadano nacional.

En tanto, al Gobierno -también paradestinatario de su mensaje- lo conminaba a impedir los paros, los actos cegetistas, las huelgas y los piquetes protagonizados por organizaciones gremiales, pues los reputaba contrarios a la civilización, a la paz social y a la estabilidad de las instituciones democráticas. La Nación, amparada en su posición ideológica por medio del recurso de la analogía y la apelación al principio de autoridad de la historia reciente, transfería al sindicalismo una actitud golpista, como lo había hecho en ocasión del derrocamiento del Gobierno peronista en 1976.

Contrariamente, el matutino nunca acusó de destituyentes, de desestabilizadores, a quienes colocaban bombas sin asumir sus responsabilidades, y si bien los ubicó como antidestinatarios, omitió conjeturar sobre la orientación ideológica de los autores de la colocación de artefactos explosivos y, lo que es peor, nunca les asignó intenciones 
César Luis Díaz, Mario Jorge Giménez

El diario La Nación versus el sindicalismo argentino. La construcción de un enemigo "subversivo" de la democracia (1983-1987)

golpistas. Al respecto, resulta elocuente su intención de endilgarle al sindicalismo propósitos contrarios a la democracia, pues su discurso llegó a equiparar a la sublevación militar de Semana Santa, de ribetes golpistas y la colocación de bombas o atentados de índole terrorista, con las exigencias sindicales en defensa de los trabajadores.

\section{Referencias}

Acusan al Gobierno por los disturbios de anteanoche. (15 de enero de 1986). La Nación. Afirmación del régimen constitucional. (18 de abril de 1987). La Nación. Agitación gremial permanente. (14 de febrero de 1986). La Nación.

Aruguete, E. (2006). Lucha política y conflicto de clases en la posdictadura. En Pucciarelli, A. (Coord.), Los años de Alfonsín. ¿El poder de la democracia o la democracia del poder? (pp. 411-460). Siglo XXI.

Atentado en la iglesia de San Ignacio. (7 de noviembre de 1985). La Nación.

Atentados criminales. (8 de octubre de 1985). La Nación.

Azpiazu, D., Basualdo, E. y Khavisse, M. (2004). El Nuevo Poder Económico en la Argentina de los Años 80. Siglo XXI.

Bloqueo de calles en la ciudad. (11 de abril de 1986). La Nación.

Bobbio, N. (2010). El futuro de la democracia. Fondo de Cultura Económica.

Bombas en la madrugada. (24 de enero de 1985). La Nación.

Borrat, H. (1989). El periódico, actor político. G. Gili.

Caligaris, H. y Ezcurra, E. (2021). Escribano. 60 años de periodismo y poder en La Nación. Planeta.

Casado, L. (2020). La "campaña del miedo" y el discurso de "mano dura" en los editoriales de La Nación durante el período alfonsinista. Actas de Periodismo y Comunicación, 5(3). https://perio.unlp.edu.ar/ojs/index.php/actas/article/view/6579.

Cifras que alarman. (9 de noviembre de 1986). La Nación.

Condena unánime de la violencia. (1 de noviembre de 1985). La Nación.

Córdoba paralizada. (16 de febrero de 1986). La Nación.

Crenzel, E. (2015). Ideas y estrategias de justicia ante la violencia política y las violaciones a los derechos humanos en la transición política en Argentina (19821983). En Feld, C. y Franco, M. (Dirs.), Democracia, hora cero. Actores, política y debates en los inicios de la posdictadura (pp. 81-114). Fondo de Cultura Económica.

Díaz, C. (2011). La Nación y Clarín frente a la violencia política 1976-1980. Dos casos de periodismo hermesiano. En Saborido, J.y Borrelli, M. (Comps.), Voces y silencios: la prensa argentina y la dictadura militar (1976-1983) (pp. 153-180). Eudeba.

Díaz, C. y Giménez, M. (2016). La Nación y el sindicalismo. La construcción editorial de un imaginario negativo. Tram[p]as de la comunicación y la cultura, (78), 65-90. https://perio.unlp.edu.ar/ojs/index.php/trampas/article/view/4223. 


\section{Austral Comunicación \\ Volumen 10, número 1 (junio de 2021): 321-347 ISSN (I) 2313-9129. ISSN (E) 2313-9137}

Díaz, C. y Giménez, M. (2017a).La Nación y el sindicalismo en 1983: la crisis, las huelgas y la democratización. Revista Internacional de Historia de la Comunicación, (9), 92-107. http://institucionales.us.es/revistarihc/documentos/rihc-09-articulo-04nacion-sindicalismo-1983.pdf.

Díaz, C. y Giménez, M. (2017b). En busca de la "República Verdadera": La Nación construyendo la transición a la democracia. Animus. Revista Interamericana de Comunicação Midiática, 16(32). https://periodicos.ufsm.br/animus/article/ view/30436.

Díaz, C. y Giménez, M. (2018a). La construcción de las bases de la democracia en los editoriales de La Nación durante los 100 primeros días del Gobierno de Alfonsín. Mediaciones, 14(21), 41-68. DOI: 10.26620/uniminuto. mediaciones.14.21.2018.41-68.

Díaz, C. y Giménez, M. (2018b). La Nación frente al sindicalismo en los albores de la democracia Argentina (1983-1985). X Jornadas de Sociología de la UNLP. La Pampa, Argentina. http://jornadassociologia.fahce.unlp.edu.ar/x-jornadas/actas/ DiazPONmesa50.pdf/view?searchterm=None.

Díaz, C., Giménez, M. y Passaro, M. (2002). La Nación y la construcción del "gran cambio". En Díaz, C., La cuenta regresiva (pp. 95-113). La Crujía.

Docentes reincorporados. (6 de julio de 1984). La Nación.

Ducrot, O. (1989). El decir y lo dicho. Hachette.

El ejercicio racional de la huelga. (7 de octubre de 1986). La Nación,

El episodio del III Cuerpo de Ejército. (5 de junio de 1986). La Nación.

El Estado y la seguridad. (22 de mayo de 1985). La Nación.

El paro general. (27 de marzo de 1986). La Nación.

Entre la concertación y las instituciones. (15 de febrero de 1986). La Nación.

Ferraresi, A. y Galasso, N. (2018). Historia de los trabajadores argentinos 1857-2018. Colihue.

Ferrer, A. (2004). La economía argentina. Desde sus orígenes hasta principios del siglo $X X I$. Fondo de Cultura Económica.

Frenkel, R. y Fanelli, J. (1986). El Plan Austral. Naciones Unidas, Comisión Económica para América Latina y el Caribe - CEPAL/Universidade Estadual de Campinas, UNICAMP, Instituto de Economia. https://repositorio.cepal.org/bitstream/ handle/11362/33116/S8600682_es.pdf?sequence=1\&isAllowed $=\mathrm{y}$.

García Lerena, R. (2007). Saúl Ubaldini: crónicas de un militante obrero peronista. Runa Comunicaciones.

Gaudio, R.y Thompson, A. (1990). Sindicalismo peronista/Gobierno radical. Los años de Alfonsín. Fundación Friedrich Ebert/Folios Ediciones.

Gillespie, R. (1987). Soldados de Perón. Los Montoneros. Grijalbo. 
César Luis Díaz, Mario Jorge Giménez

El diario La Nación versus el sindicalismo argentino. La construcción de un enemigo "subversivo" de la democracia (1983-1987)

Gordillo, M. (Comp.). (2019). 1969. A cincuenta años: repensando el ciclo de protesta. CLACSO. http://biblioteca.clacso.edu.ar/clacso/se/20191204035716/Repensandoel-ciclo-de-protestas.pdf.

Innecesaria amenaza a la paz social. (18 de enero de 1985). La Nación.

Iñigo Carrera, N. (2001). Las huelgas generales, Argentina 1983-2001: un ejercicio de periodización. PIMSA. Documento de Trabajo ${ }^{\circ} 33$. http://www.pimsa.secyt.gov. ar/publicaciones/DT\%2033.pdf.

Kerbrat-Orecchioni, C. (1997). La enunciación. De la subjetividad en el lenguaje. Edicial.

La metodología de las bombas. (25 de junio de 1987). La Nación.

La reforma laboral y el Congreso. (31 de julio de 1986). La Nación.

La teoría del hombre malo. (28 de enero de 1987). La Nación.

La violencia como argumento. (2 de junio de 1984). La Nación.

Laclau, E. (2010). La razón populista. Fondo de Cultura Económica.

Los paros y el suministro eléctrico. (13 de mayo de 1986). La Nación.

Los servicios eléctricos. (28 de mayo de 1986). La Nación.

Maingueneau, D. (1989). Introducción a los métodos de análisis del discurso. Hachette.

Metodología de las bombas. (2 de mayo de 1985). La Nación.

Nuevos gobernadores y el paro de la CGT. (11 de diciembre de 1987). La Nación.

Otra vez la violencia en las calles. (17 de enero de 1986). La Nación.

Przeworski, A. (2010). Qué esperar de la democracia. Siglo XXI.

Rapoport, M. (2003). Historia económica, política y social de la Argentina, 1880-2000. Ediciones Macchi.

Rodrigo Alsina, M. (1991). Los medios de comunicación ante el terrorismo. Icaria.

Saborido, J y Borrelli, M. (2014). Por la "dignidad Militar": la revista Cabildo y el levantamiento carapintada en la Semana Santa de 1987. La Trama de la Comunicación, (18), 293-311. https://rephip.unr.edu.ar/handle/2133/3569.

Senén González,S.y Bosoer,F.(1993). La trama gremial 1983-1989 crónica y testimonios. Corregidor.

Sidicaro, R. (1993). La política mirada desde arriba. Sudamericana.

Sivak, M. (2015). Clarín. La era Magnetto. Planeta.

Steimberg, O. (2000). Naturaleza y cultura en el ocaso (triunfal) del periodismo amarillo. CIC. Cuadernos de Información y Comunicación, (5), 235-240. https:// www.redalyc.org/articulo.oa?id=93500512.

Un delito con anuncio previo. (24 de diciembre de 1983). La Nación.

Un nuevo conflicto en el Correo. (18 de mayo de 1986). La Nación.

Vasilachis, I. (1992). Métodos cualitativos I. Los problemas teórico-espistemológicos. Centro Editor de América Latina. 
Austral Comunicación

Volumen 10, número 1 (junio de 2021): 321-347 ISSN (I) 2313-9129. ISSN (E) 2313-9137

Verón, E. (2005). Fragmentos de un tejido. Gedisa.

Violencia callejera en Córdoba. (28 de marzo de 1985). La Nación.

Vommaro, P. y Cozachcow, A (2018). Militancias juveniles en los 80: Acercamientos a las formas de participación juveniles en la transición democrática argentina. Trabajo $y$ Sociedad, (30), 285-306. https://www.unse.edu.ar/trabajoysociedad/30\%20 VOMMARO\%20COZACHCOW\%20militancias\%20juveniles\%20REV.pdf. 